\title{
Factors Present in Serum and Seminal Plasma which Promote Germ-tube Formation and Mycelial Growth of Candida albicans
}

\author{
By A. J. E. BARLOW AND T. ALDERSLEY \\ Department of Dermatology, Huddersfield Royal Infirmary, Huddersfield, Yorkshire \\ AND F. W. CHATTAWAY \\ Department of Biochemistry, University of Leeds, Leeds $L S_{2}{ }_{9} L S$
}

(Received 21 November 1973; revised 22 January 1974)

\begin{abstract}
SUMMARY
Factors have been concentrated from human serum and seminal plasma which, in the presence of glucose and at $37^{\circ} \mathrm{C}$, will induce germination and support mycelial development of blastospores of Candida albicans. The most active fraction from serum contained $98 \%$ albumin but the inactivity of a number of commercial samples of albumin and comparison with the factor from seminal plasma indicated that the active component was probably not albumin. The active fraction from seminal plasma was of lower molecular weight than that from serum and had considerably greater germ-tube producing activity/mg protein. Mycelial development in serum declined after $24 \mathrm{~h}$ incubation but removal of cells at this time and reinoculation again gave rise to mycelial growth. An inhibitor of germination (but not of growth) accumulated after 3 to 6 days. Many non-peptide components of serum have been tested for germ-tube-producing activity with negative results.
\end{abstract}

\section{INTRODUCTION}

The development of germ tubes when blastospores of Candida albicans are incubated in serum at $37^{\circ} \mathrm{C}$ for 2 to $6 \mathrm{~h}$ is used routinely as a means of identification of this yeast. The exact nutritional requirements for the change in morphology have never been clearly defined. In clinical disease, especially infection of the oral cavity, skin and nails, as for example in chronic mucocutaneous candidiasis, the mycelial form of growth predominates (Gresham \& Whittle, 1961). The change in growth form from blastospores to germ tubes could well be a factor influencing the pathogenicity of Candida albicans (Taschdjian \& Kozinn, 1957).

The importance of temperature in relation to morphology has been recognized by a number of workers. Using a neopeptone medium with starch as the main source of carbohydrate, Chattaway, Holmes \& Barlow (1968) showed that Candida albicans would grow as blastospores at $30^{\circ} \mathrm{C}$ and as mycelium at $40^{\circ} \mathrm{C}$, mycelial development being maximal at $4 \mathrm{~h}$. This difference in temperature produced significant changes in wall composition between the two forms. Subsequently, changes in the activity of a number of enzymes and intracellular concentrations of intermediates were demonstrated in the two forms examined at intervals over an $\mathrm{I} 8 \mathrm{~h}$ period of growth (Chattaway et al. 1973).

Some development of germ tubes or mycelium in simple media has been demonstrated by a number of workers. Thus, using a simple basal medium with ammonium sulphate as a source of nitrogen and glucose as a source of carbohydrate, Nickerson \& Mankowski 
(I953) found that in slide cultures at $25^{\circ} \mathrm{C}$ for 4 days, Candida albicans grew in the yeast phase, but replacement of glucose by purified starch, glycogen or dextrin resulted in diminished growth and extensive filamentation. They postulated that the rapid metabolism of glucose produced free thiol groups which were essential for the development of the yeast phase. Robson \& Stockley (1962) produced supporting evidence for this theory when they demonstrated in autoradiographs free-SH groups in the round cells but not in the filaments of C. albicans grown on potato agar at 22 and $30^{\circ} \mathrm{C}$. Widra (1964) found that mycelium formation on neopeptone-glucose-phosphate agar medium at $37^{\circ} \mathrm{C}$ was good and that the extent of mycelium production was dependent upon the glucose:phosphate ratio. He concluded that cell division required the production of reducing groups and the presence of free intracellular magnesium ions; lack of either resulted in filamentation. Other simple media used for mycelium formation were: glycine, glucose, yeast extract (De Palma, 1966); glucose, salts, biotin and amino acids (Mardon, Balish \& Philips, I969); tissue culture medium I99 or proline-biotin phosphate buffer (Dabrowa, 197I).

Taschdjian \& Kozinn (196I) studied the growth of Candida albicans in serum and serum dialysates at $37^{\circ} \mathrm{C}$. They showed that cultures grew well in dialysates, and converted into the mycelial phase in 6 to $8 \mathrm{~h}$, but that after $24 \mathrm{~h}$ the yeast phase predominated. Glucose was exhausted in 12 to $14 \mathrm{~h}$ and amino acids after 5 days. They suggested that the maintenance of the mycelial form in tissues was dependent upon the utilization of free amino acids, and showed mixed yeast and mycelial growth on glucose plus a mixture of the amino acids found in serum. Caroline, Taschdjian, Kozinn \& Schade (1964) claimed that growth would not occur in normal serum at $37^{\circ} \mathrm{C}$ unless the iron-binding capacity of the transferrin was saturated. This is difficult to reconcile with the use of serum as a medium for identification of the organism. The answer may lie in the very small inocula used by these authors, the 'carry over' of iron in larger inocula being sufficient to satisfy the iron requirement for growth. They did not comment on the growth form obtained under their conditions. Bernander \& Edebo (I 969 ) showed that the addition of bovine serum albumin to a synthetic medium at $37^{\circ} \mathrm{C}$ enhanced the yield of mycelium and that the albumin was not utilized.

The present investigators have examined the nature of the components of serum which are responsible for inducing formation of germ tubes and mycelium and the conditions under which these components are formed. In view of the results obtained, other tissue fluids were examined under similar conditions and significant results were obtained when seminal plasma was the substrate. A preliminary report of some of this work has been given (Barlow \& Chattaway, 197I).

\section{METHODS}

Nomenclature. The term 'germ tube' has been used to define the filamentation which develops from blastospores of Candida albicans when incubated in serum at $37^{\circ} \mathrm{C}$ for 2 to $6 \mathrm{~h}$. When incubation is continued, germ tubes elongate into hyphae with blastospore production at hyphal junctions. If growth is allowed to continue for $24 \mathrm{~h}$, a mycelial mat develops with an admixture of blastospores in proportions depending on the medium.

Organism. Primary isolates of Candida albicans (strains Ca I and Ca 2) from two patients suffering from chronic mucocutaneous candidiasis were freeze-dried and used for all experiments. Fresh isolates from other clinical cases were also used.

Tissue fluids. Normal pooled serum and individual sera were separated fresh and stored at $-20^{\circ} \mathrm{C}$. Semen from normal human males and from human males after vasectomy were obtained from a fertility clinic. Bovine semen was obtained from the Milk Marketing Board, Cattle Breeding Centre, Burley-in-Wharfedale, Yorkshire. Spermatozoa were removed by 
centrifugation and the seminal plasma stored at $-20^{\circ} \mathrm{C}$. Cerebrospinal fluid (CSF) samples were biochemically and microbiologically normal and were obtained from hospital patients, urine and saliva samples were from normal adults, bile samples were from surgical patients, and milk was from commercial samples of treated and untreated cow's milk.

Estimation of growth. The extent of germ-tube production was determined by the inoculation of $0.5 \mathrm{ml}$ serum, or other medium of $\mathrm{pH} 7.4$, with $4 \times 10^{4}$ blastospores harvested from Sabouraud's glucose agar slopes after $\mathrm{I} 6 \mathrm{~h}$ incubation at $30^{\circ} \mathrm{C}$. The cells were washed twice in distilled water. The test medium was incubated at $37^{\circ} \mathrm{C}$ in stationary culture and germtube production measured in a haemocytometer at 2,4 and $6 \mathrm{~h}$. The relative proportions of mycelium and blastospores were measured according to Chattaway et al. (1973). Total growth was measured after inoculation of $10 \mathrm{ml}$ test medium $\left(\mathrm{pH} \mathrm{7.4)}\right.$ with $\mathrm{I} \times 10^{6}$ blastospores and incubating at $37^{\circ} \mathrm{C}$ in a $100 \mathrm{ml}$ conical flask in a Greenfield LTE reciprocating shaker at 50 strokes/min for $24 \mathrm{~h}$. The contents of the flask were transferred quantitatively to a dried, weighed centrifuge tube. The organisms were spun down, washed three times by suspension in distilled water and dried at $100^{\circ} \mathrm{C}$ overnight.

Chemical determinations. Protein was assayed by the method of Lowry, Rosebrough, Farr \& Randall (I95I) with bovine serum albumin (Sigma) as a standard, calcium by the method of Gittleman (1967), phosphorus by the method of Young (1966), serum iron and total iron binding capacity by the method of Young \& Hicks (1965), urea by the method of Marsh, Fingerhut \& Miller (1965), total cholesterol by the method of Annan \& Isherwood (1969), and ethanol by the method of Nickolls (1960). The utilization of free amino acids in serum was demonstrated by paper chromatography. Lipids were extracted from serum by shaking I vol. serum with 5 vol. chloroform/methanol (I: I, v/v).

Gel filtration. This was carried out at $4{ }^{\circ} \mathrm{C}$ by using (i) Sephadex G-200 equilibrated with $0.2 \mathrm{M}-\mathrm{NaCl}$ in $0 . \mathrm{I} \mathrm{M}$-tris- $\mathrm{HCl}$ at $\mathrm{pH} 8$ on a column $(2.5 \times 100 \mathrm{~cm})$ and eluting with the same buffer, or (ii) Sephadex G-50 equilibrated with $0.05 \mathrm{M}$-tris- $\mathrm{HCl}$ at $\mathrm{pH} 7$ on a column $(2.5 \times$ $40 \mathrm{~cm}$ ) and eluting with the same buffer. Eluates were monitored by inline L.K.B. Uvicord at $280 \mathrm{~nm}$.

Ion-exchange chromatography. DEAE A50-Sephadex ion-exchange gel was equilibrated at $4{ }^{\circ} \mathrm{C}$ with $0.1 \mathrm{M}$-tris- $\mathrm{HCl}$ at $\mathrm{pH} 7$ and a linear $\mathrm{NaCl}$ gradient from 0.05 to $0.6 \mathrm{M}$ in $500 \mathrm{ml}$ applied. Eluates were monitored as above.

Isoelectric focusing. This was performed at $4^{\circ} \mathrm{C}$ by using an L.K.B. $440 \mathrm{ml}$ I.E.F. column with standard sucrose density gradient with $\mathrm{I} \%$ ampholine (pH range 3 to 6 ) at a constant current of 6 watts. Eluates were monitored as above.

Gel electrophoresis. Samples containing $120 \mu \mathrm{g}$ protein were run in polyacrylamide gels $(7.5$ or $10 \%)$ in tris $(5 \mathrm{mM})+$ glycine $(38 \mathrm{~mm})$ buffer, $\mathrm{pH} 8.3$, for $80 \mathrm{~min}$ at $2 \mathrm{~mA} /$ gel and were stained with Coomassie blue (0.05\%).

\section{RESULTS}

\section{Factors affecting mycelial development in serum}

Temperature. When Candida albicans was grown in serum at $20^{\circ} \mathrm{C}$ growth was almost entirely as blastospores. As the temperature was increased to $37^{\circ} \mathrm{C}$, the growth form changed to germ tubes and subsequently mycelium, with significantly more growth as shown by dry weight determination (Table I).

Sugars. After incubation of Candida albicans in serum at $37^{\circ} \mathrm{C}$, growth continued as mycelium for $24 \mathrm{~h}$ after which there was reduced growth as blastospores. All glucose in 
Table I. Effect of temperature on germ-tube formation and growth of Candida albicans in serum

$\begin{array}{cccc}\begin{array}{c}\text { Temperature } \\ \left({ }^{\circ} \mathrm{C}\right)\end{array} & \begin{array}{c}\text { Germ tubes } \\ \text { after 6 h } \\ (\%)\end{array} & \begin{array}{c}\text { Mycelium } \\ \text { after } 24 \mathrm{~h} \\ (\%)\end{array} & \begin{array}{c}\text { Dry weight } \\ \text { after } 24 \mathrm{~h} \\ (\mathrm{mg} / \mathrm{I} 0 \mathrm{ml})\end{array} \\ 20 & 10 & & 7 \cdot 1 \\ 30 & 40 & 10 & 10 \cdot 0 \\ 37 & 90 & 85 & 14.2\end{array}$

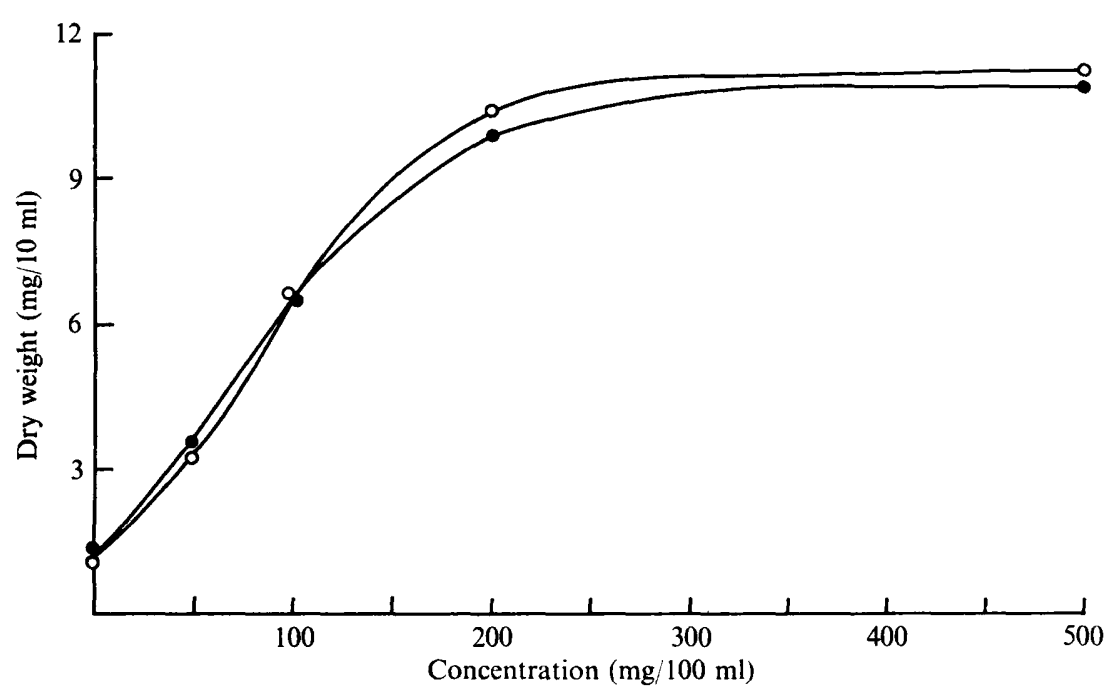

Fig. I. Effect of sugar concentration on the growth of Candida albicans for $24 \mathrm{~h}$ in serum at $37{ }^{\circ} \mathrm{C}$, after an initial incubation for $24 \mathrm{~h}$ to exhaust endogenous glucose. $\bullet$, Glucose; $O$, fructose.

the supernatant medium had been utilized; when this was restored to physiological levels the growth form again became mycelial. Fructose, galactose and sucrose could be substituted for glucose. The effect of variation in the concentrations of glucose and fructose on growth for a further $24 \mathrm{~h}$ after the initial $24 \mathrm{~h}$ in serum only, are shown in Fig. I. Since maximum growth occurred at $0.2 \%(w / v)$ glucose, this concentration was adopted for all subsequent experiments.

When serum ( $10 \mathrm{ml}$ ) was inoculated with $10^{6}$ blastospores and incubated for $24 \mathrm{~h}$, the growth centrifuged off and the supernatant re-inoculated, growth continued as mycelium. This procedure could be continued for 3 to 5 days providing that free glucose was present, the actual number of days before there was no growth on re-inoculation varying with individual sera. When the final supernatant was passed down a G-25 Sephadex column the resultant eluate supported growth and maximal germ-tube production, thus showing that cessation of growth had been due to inhibitory compounds produced by the yeast. Some chemical changes in serum at the end of several days growth are shown in Table 2.

Serum proteins. When serum was subjected to repeated ultrafiltration by using an Amicon Diaflo ultrafilter, PM-30 membrane, with a cut-off at molecular weight 25000 , the factors responsible for germ-tube production in the presence of free glucose were present in the residue in association with the serum proteins and not in the ultrafiltrate.

Separation of the serum proteins by passage down a Sephadex G-200 column showed 
Table 2. Changes in serum after daily re-inoculation with Candida albicans

No significant change in urea, protein, cholesterol, $\mathrm{Ca}, \mathrm{Fe}, \mathrm{P}$. Free amino acids completely utilized.

$\begin{array}{ccccc}\begin{array}{c}\text { Glucose } \\ \text { supplement }\end{array} & \text { Day } & \begin{array}{c}\text { Dry wt } \\ (\mathrm{mg} / \mathrm{IO} \mathrm{ml})\end{array} & \begin{array}{c}\text { Ethanol } \\ (\mathrm{mg} / \mathrm{ml})\end{array} & \begin{array}{c}\text { Glucose } \\ \text { utilized }(\mathrm{g})\end{array} \\ + & 3 & 16 \cdot 8 & 6.4 & - \\ - & 6 & 29 \cdot 6 & 11 \cdot 5 & 2.5 \\ - & 3 & 3.2 & 0.14 & - \\ & 6 & 8.0 & - & 0 . \mathrm{I}\end{array}$

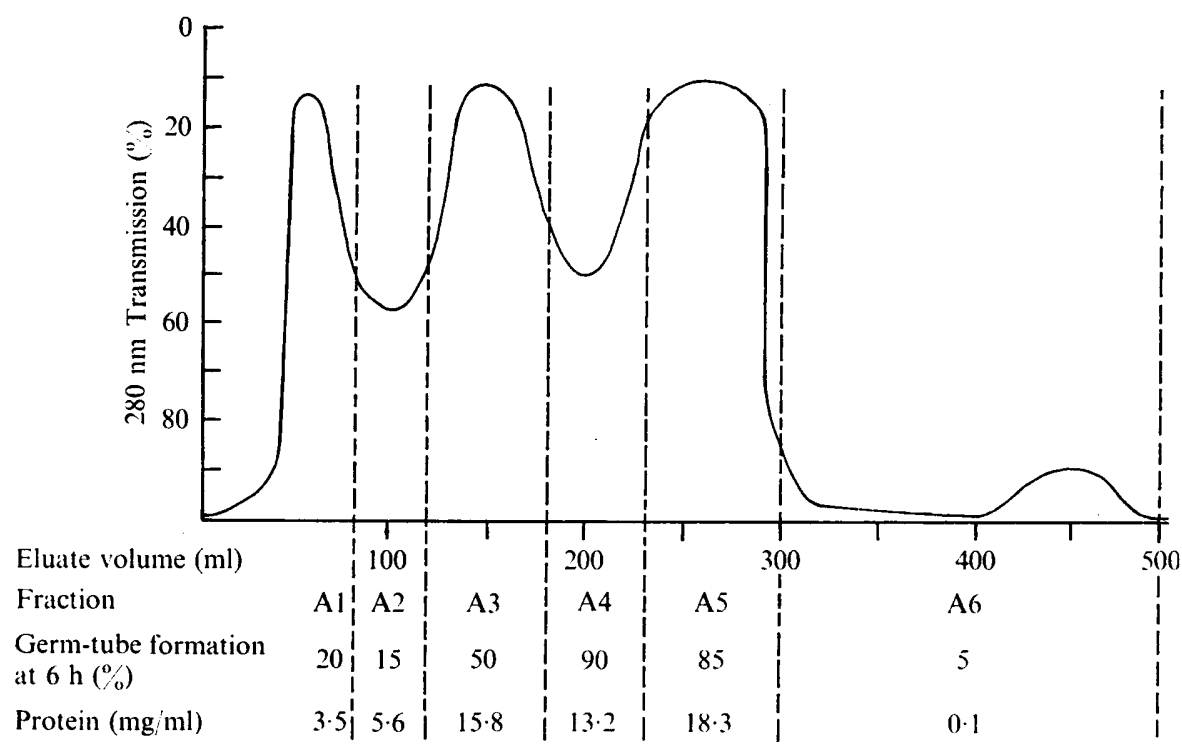

Fig. 2. Fractionation of human serum on Sephadex G-200.

germ-tube producing activity to be maximal in the third peak, fractions $\mathrm{A}_{4}$ and A5 (Fig. 2). Electrophoresis showed these to be mainly albumin. Fractions $\mathrm{A}_{4}$ and A5 were combined and further fractionated by ion-exchange chromatography on DEAE-A50-Sephadex. This yielded four main peaks with germ-tube producing activity mainly in the fraction with the highest protein content (B3, Fig. 3). When fraction B3 was examined by iso-electric focusing in the range $\mathrm{pH} 3$ to 6 , two main peaks were demonstrated, germ-tube producing activity being concentrated in fraction $\mathrm{C}_{5}$ which was eluted at $\mathrm{pH} 5.8$ (Fig. 4). This fraction ran as a single band in acrylamide gel $(7.5 \%)$ electrophoresis and examination in the ultracentrifuge showed it to be at least $98 \%$ pure albumin. However, examination of this material by crossed immunoelectrophoresis against whole human antiserum revealed the presence of nine components.

Earlier experiments using a commercial crystalline Cohn fraction-5 human albumin in the presence of $0.2 \%(\mathrm{w} / \mathrm{v})$ glucose had produced only $15 \%$ germ tubes. In view of the results of the above fractionation other preparations of ovine, bovine and human albumin were examined under similar conditions for germ-tube production and the results are shown in Table 3 . These demonstrate that certain commercial preparations of serum albumin will support germ-tube production whilst others are relatively inactive. In order to show that growth was also sustained, a growth experiment as described under 


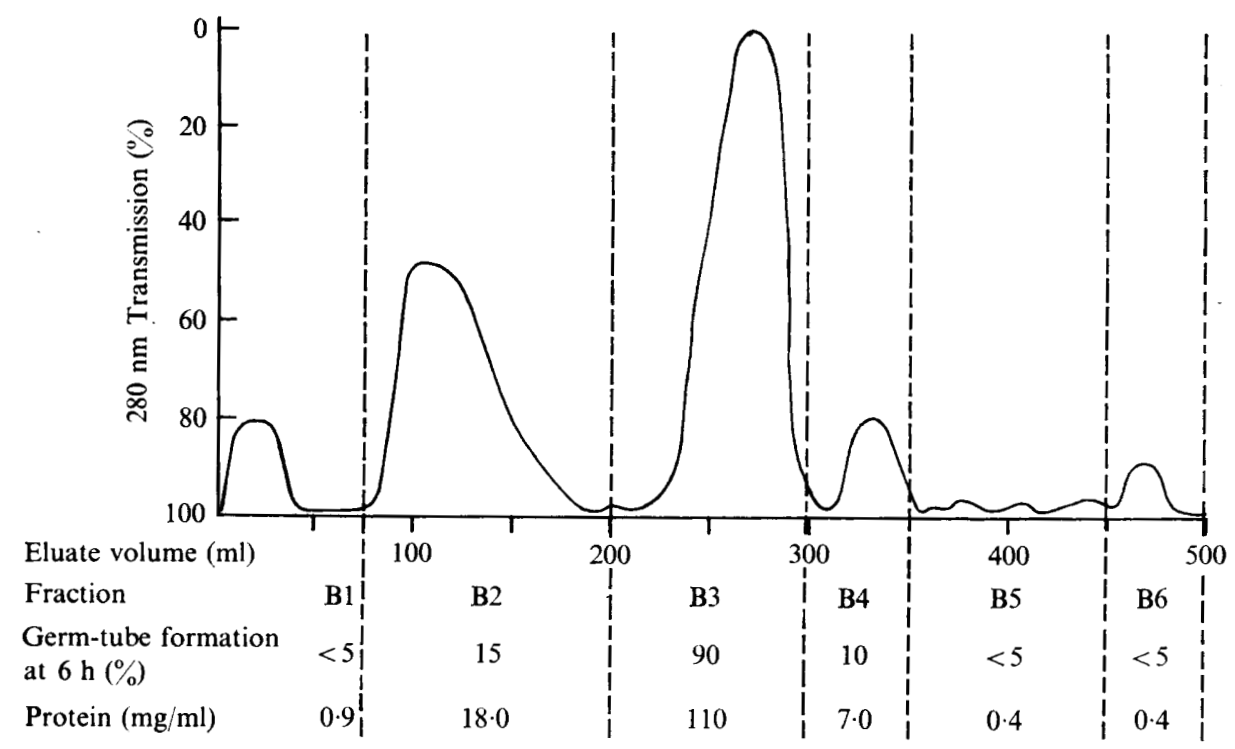

Fig. 3. Fractionation on Sephadex DEAE-A50 of fractions $\left(\mathrm{A}_{4}+\mathrm{A}_{5}\right)$ from serum showing maximum germ-tube forming activity after passage down Sephadex G-200.

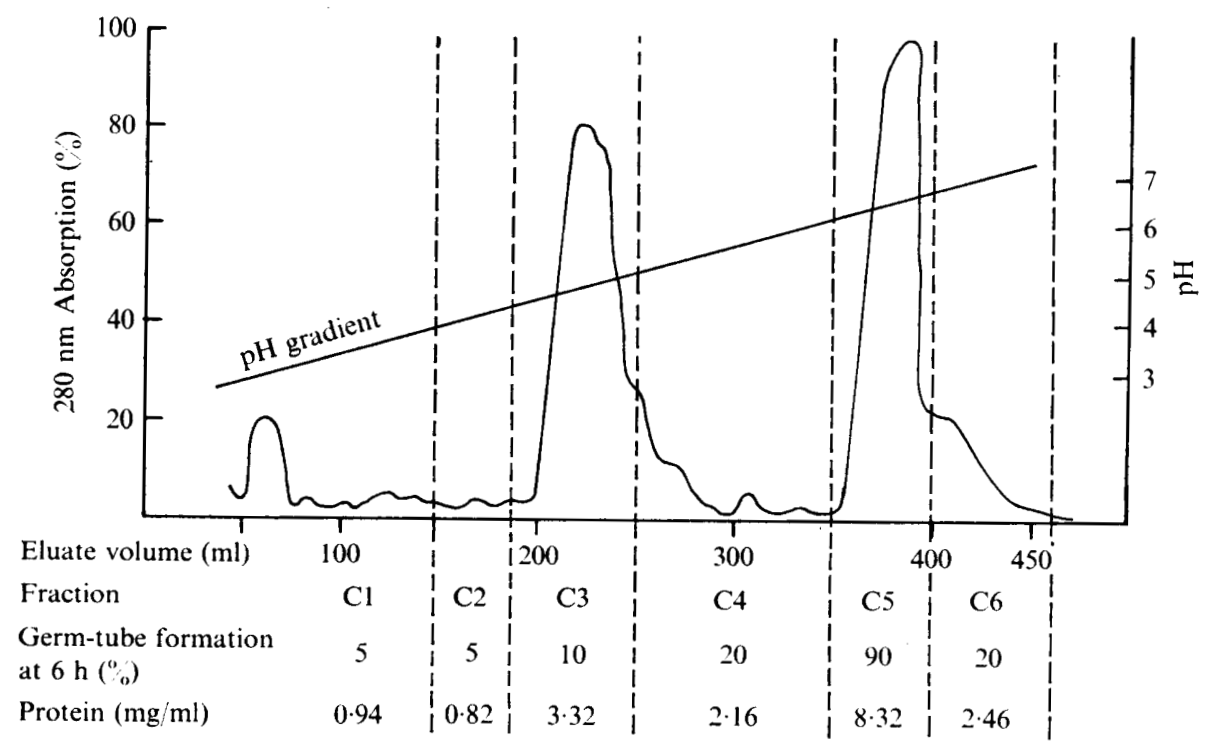

Fig. 4. Fractionation by isoelectric focusing of the fraction $\left(B_{3}\right)$ showing maximum germ-tube forming activity prepared from serum by passage down Sephadex G-200 and Sephadex DEAE-A50.

Methods was carried out using $2 \%$ (w/v) albumin (Koch Light Human Cohn Fraction 5) with $0.2 \%$ glucose: after $24 \mathrm{~h}$ this yielded $50 \%$ mycelium and $7.0 \mathrm{mg}$ dry weight/ $/ 0 \mathrm{ml}$.

These findings suggested that the active principle might be carried by the albumin. This could not be non-esterified fatty acids, because of the high activity of the Sigma bovine fatty-acid-free albumin and the high activity of fresh serum previously extracted with chloroform/methanol. 
Table 3. Germ-tube production by Candida albicans from albumins purchased commercially

(20 $\mathrm{mg}$ albumin $/ \mathrm{ml}, 2 \mathrm{mg}$ glucose $/ \mathrm{ml}$ )

\begin{tabular}{lllc} 
Source & Manufacturer & \multicolumn{1}{c}{ Description } & $\begin{array}{c}\text { Germ tubes } \\
\text { (\%) }\end{array}$ \\
Human & Calbiochem & Cohn Fraction 5 & 15 \\
Ovine & Sigma & Cohn Fraction 5 & 35 \\
Bovine & Sigma & Crystallized and lyophilized & 80 \\
Bovine & Sigma & Essentially fatty acid free & 90 \\
Human & Koch-Light & Cohn Fraction 5 & 80 \\
Human & Beringwerke & Electrophoretic purity 100 \% & 85 \\
Human & Sigma & Cohn Fraction 5 & 15
\end{tabular}

Table 4. Effect of iron on growth of Candida albicans in serum

Normal serum, glucose $0.2 \%(\mathrm{w} / \mathrm{v})$, ascorbic acid $2.5 \mu \mathrm{g} / 100 \mathrm{ml}$. Iron added as ferrous ammonium sulphate. Incubation $24 \mathrm{~h}$.

$\begin{array}{ccclc}\begin{array}{c}\text { Incubation } \\ \text { temperature } \\ \left({ }^{\circ} \mathrm{C}\right)\end{array} & \begin{array}{c}\text { Fe } \\ (\mu \mathrm{g} / \mathrm{I} 00 \mathrm{ml})\end{array} & \begin{array}{c}\text { Fe binding } \\ \text { capacity } \\ \text { (\% saturation) }\end{array} & \text { Growth form } & \begin{array}{c}\text { Dry wt } \\ (\mathrm{mg} / \mathrm{I} 0 \mathrm{ml})\end{array} \\ 20 & 90 & 25 & \text { Blastospores } & 1 \cdot 5 \\ & 440 & 125 & \text { Blastospores } & 4 \cdot 7 \\ 37 & 90 & 25 & \text { Mycelium } & 17 \cdot 0 \\ & 440 & 125 & \text { Mycelium } & 25 \cdot \mathrm{I}\end{array}$

Experiments with diluted serum. Serum could be diluted with Ringers solution to give approximately $50 \%$ germ-tube production. Such a preparation, maintaining glucose at $0.2 \%$, was used to assess germ-tube production after a series of normal serum constituents had been added to bring their concentration to physiological levels. The dilution required was of the order of $\mathrm{I}: \mathrm{I} 5$, there being some variation between sera. The additions included a wide range of amino acids, singly and in groups, steroid hormones, squalene, sterols, mucopolysaccharides, vitamins, calcium and other metals. Similar experiments were performed using ergosterol, fluorinated steroids, chelating agents and a series of cytotoxic drugs. In no instance was germ-tube production significantly raised or decreased as compared with controls.

Iron. The effect of adding iron to serum was examined in view of the findings of Caroline et al. (1964) that with low inocula, growth did not occur in serum until the iron binding capacity was saturated. The addition of ferrous ammonium sulphate, in order to effect this and to leave free ferrous ions, produced increased growth at 20 and $37^{\circ} \mathrm{C}$ (Table 4). Since appreciable growth occurred before the addition of iron it appears that saturation of the transferrin is not essential. The increased growth did not result in any change in morphology and growth was mycelial at $37^{\circ} \mathrm{C}$.

\section{Growth in tissue fluids other than serum}

A series of other tissue fluids was then examined for their capacity to induce germ-tube production in the presence of free glucose (Table 5). They all showed the capacity to do so but, with the exception of seminal plasma, were less effective than serum.

Seminal plasma. Fractionation of human and bovine seminal plasma on Sephadex G-200 under identical conditions to those used in experiments with serum gave an additional peak. This peak followed the albumin fraction (Fig. 5, and cf. Fig. 2) and showed very high 
Table 5. Germ-tube production by Candida albicans in tissue fluids other than serum

Ten samples of each fluid were examined.

$\begin{array}{lcc}\quad \text { Tissue fluid } & \begin{array}{c}\text { Range of germ-tube production at } 6 \mathrm{~h}(\%) \\ \text { Without added } \\ \text { glucose }\end{array} & \begin{array}{c}\text { Glucose (final } \\ \text { concentration } 0 \cdot 2 \%)\end{array} \\ \text { Urine } & 5 & 5-20 \\ \text { C.S.F. } & 15-25 & 15-25 \\ \text { Saliva } & 10-30 & 30-60 \\ \text { Bile } & 5-10 & 30-50 \\ \text { Milk } & 5 & 10-15 \\ \text { Seminal plasma } & 90-99 & 90-99 \\ \quad \text { Normal human } & 90-99 & 90-99 \\ \text { Post-vasectomy human } & 90-99 & 90-99 \\ \text { Bovine } & & \end{array}$

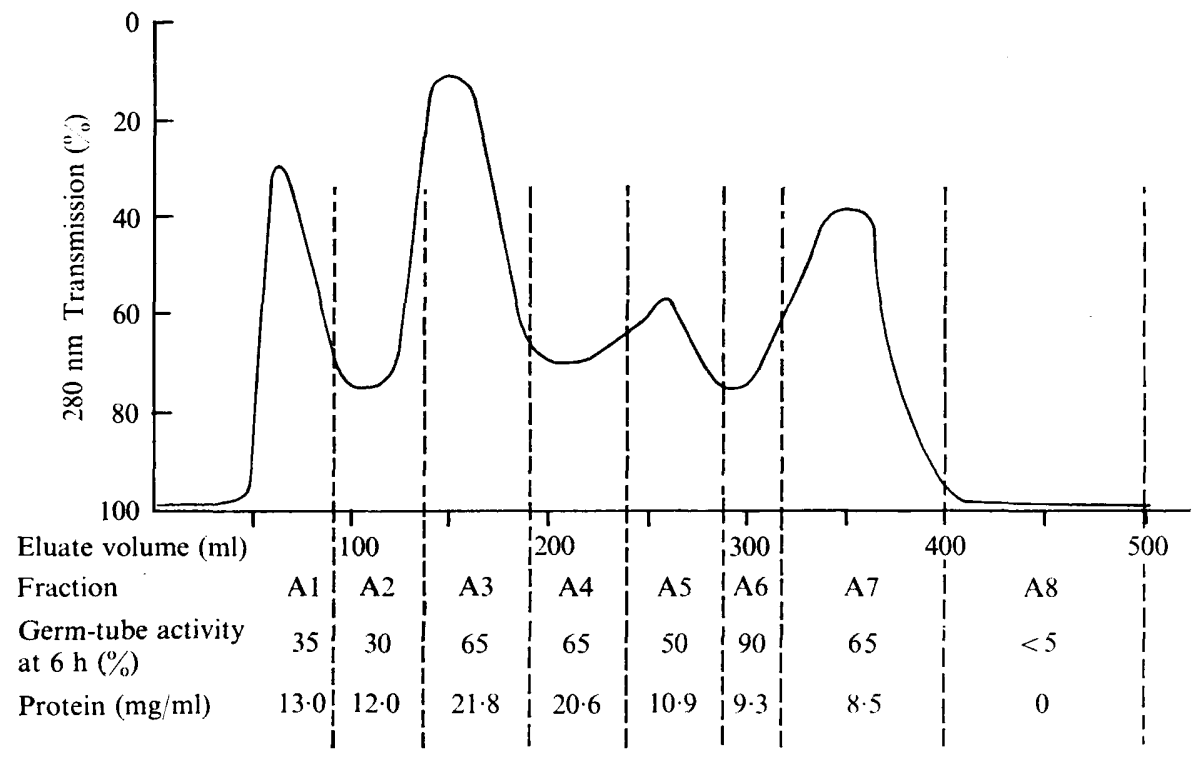

Fig. 5. Fractionation of bovine seminal plasma on Sephadex G-200.

germ-tube production associated with relatively low protein content and was of smaller molecular size than the active fraction in serum. Bovine seminal plasma was therefore fractionated on Sephadex G-50 (Fig. 6). This produced three main fractions and germ-tube production was maximal in fraction D2 (Fig. 6) which corresponded to a molecular size of I 500 to 5000 . Examination of this fraction by electrophoresis in $10 \%(w / v)$ acrylamide gel revealed two major and six minor peptide components, but separation by isoelectric focusing was impossible owing to precipitation. 


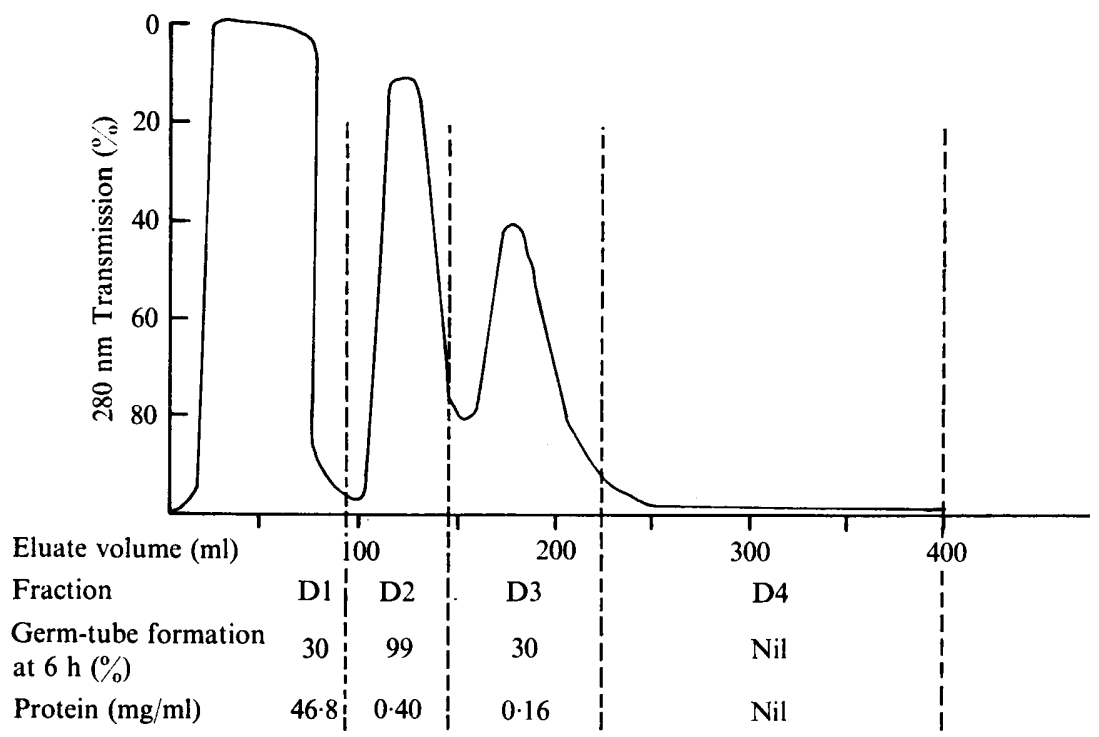

Fig. 6. Fractionation of bovine seminal plasma on Sephadex G-50.

\section{DISCUSSION}

The development of a germ tube from a blastospore of Candida albicans appears to require three environmental factors. Firstly, a temperature of $37^{\circ} \mathrm{C}$ or above: this has been found by the majority of workers, the principal exceptions being Nickerson \& Mankowski (1953) who induced filamentation at $25^{\circ} \mathrm{C}$ in slide cultures. Secondly, a glucose concentration of approximately $0.1 \%$ or greater; most workers with synthetic or semi-synthetic media have included glucose, although Nickerson \& Mankowski (I953) obtained filamentation on their synthetic medium only when the glucose was replaced by a polysaccharide, and Chattaway et al. (I968) obtained good yields of mycelium on a neopeptone-starch medium. The present work with serum as the basal medium has shown that, in the absence of glucose, germ tubes do not develop, although limited growth as blastospores does take place (Table 2). Thirdly, a factor or factors which in the present work have been obtained from either serum or seminal plasma. Separation of the material from serum led to the isolation of a product which was at least $98 \%$ albumin. That the active material was not albumin itself was indicated by the low activity of some samples of albumin (Table 3). This suggested that it was either a minor protein component of the albumin (and immunoelectrophoresis revealed the presence of eight proteins), or it was material associated with, or part of, the albumin or other protein and was released by the organism. The latter appeared the more likely possibility with the demonstration that the most active fraction from seminal plasma was of much lower molecular weight than that from serum. That this material has much greater germ-tube producing activity/mg protein than that from serum can be seen from the activity of diluted samples (Table 6). It can be deduced that the minimum quantity of protein in serum fraction $\mathrm{C}_{5}$ required to give $90 \%$ germ-tube formation is $7.4 \mathrm{mg} / \mathrm{ml}$, while that from seminal plasma fraction $D_{2}$ is $0.16 \mathrm{mg} / \mathrm{ml}$. Dialysis of either of these fractions by using membranes which retained the peptide material did not lessen their activity, and thus if material was released to induce germ tube formation it was probably as a result of enzymic action by the organism. Further study of the nature of these materials is in progress. It has 
Table 6. Comparison of germ-tube production in serial dilutions of serum and seminal plasma and their respective active fractions

\begin{tabular}{|c|c|c|c|c|}
\hline & \multicolumn{4}{|c|}{ Germ-tube formation at $6 \mathrm{~h}(\%)$} \\
\hline & \multicolumn{2}{|c|}{ Serum } & \multicolumn{2}{|c|}{ Seminal plasma } \\
\hline & Whole & $\begin{array}{l}\text { Fraction } \mathrm{C}_{5} \\
\quad \text { (Fig. 4) }\end{array}$ & Whole & $\begin{array}{l}\text { Fraction D2 } \\
\text { (Fig. 5) }\end{array}$ \\
\hline Protein content $(\mathrm{mg} / \mathrm{ml}) \ldots$ & 80 & $8 \cdot 32$ & 47 & 0.40 \\
\hline $\begin{array}{c}\text { Concentration in } \\
\text { Ringer's solution }(\%, v / v)\end{array}$ & & & & \\
\hline 5 & 35 & 8 & 35 & 30 \\
\hline IO & 80 & 20 & 60 & 50 \\
\hline 20 & 90 & 35 & 80 & 85 \\
\hline 40 & 95 & 35 & 95 & 90 \\
\hline 60 & 95 & 55 & 95 & 95 \\
\hline 80 & 95 & 80 & 95 & 95 \\
\hline 100 & 99 & 99 & 99 & 99 \\
\hline
\end{tabular}

been shown, in agreement with the observation of Bernander \& Edebo (1969), that there was no detectable reduction in the amount of albumin present after germ-tube formation and mycelial growth for up to 6 days, but this could have been due to the release by the organism from albumin of non-peptide material or of a small peptide which would not significantly alter the protein estimation. That peptides which affect the growth of cells are present, associated with serum proteins, is also indicated by the isolation of a tripeptide from albumin and $\alpha$-globulin which stimulates the growth of hepatomas and prolongs the survival of normal liver cells (Pickart \& Thaler, 1973). While attention has been concentrated on the most active fractions from serum and seminal plasma, significant germ-tube producing activity was also present in other protein fractions of higher molecular weight. Possibly the organism is able to release active material from a range of proteins, the extent of activity varying with different proteins.

The results described are not easily reconcilable with those of Taschdjian \& Kozinn (196I) in that no germ-tube formation was found during growth on serum dialysates or mixtures of free amino acids at the same concentration as in serum, but comparison is difficult since these authors did not describe the membrane used in their dialysis or quantify the extent of mycelium formation. That the free amino acids of serum are not involved in mycelium development is also indicated by its continued formation on serial re-inoculation of serum after exhaustion of the free amino acid content (Table 2).

The three factors which are responsible for germ-tube formation are in accord with some clinical observations. Thus Van Uden (I961) showed that Candida albicans is a common commensal in the alimentary tract of warm-blooded animals and birds (especially those on a diet with a high carbohydrate content), humans, fowls and turkeys being the natural hosts. The increased filamentation which occurred in serum (Table I) and other tissue fluids with increase in temperature supports the widely held view that $C$. albicans invades tissues in the mycelial form. It is at mammalian and avian body temperatures that clinical disease develops.

Patients suffering from diabetes are recognized to be prone to Candida infections, particularly vulvo-vaginitis and balanitis. Fig. I shows the effect of increasing concentrations of glucose when Candida albicans is incubated in serum. After $24 \mathrm{~h}$ mycelium production reached an average maximum of $60 \%$ at $0.1 \%$ glucose and the amount of growth was maximal at $0.2 \%$. This is a concentration more regularly maintained in the serum and tissue 
fluids of diabetic patients than in those of controls. Patients with such levels of glucose could well be exposed to considerably larger amounts of growth of the yeast than those in the normal range. Spellacy \& Carlson (1965) showed an increase in blood-glucose concentration in patients on oral contraceptives, increases which are reflected in the composition of vaginal secretions. There is conflicting evidence about an increased incidence of candidiasis in such patients, but Walsh, Hildebrandt \& Prystowsky (1968) suggested that such an increase was related to the changes in blood-glucose concentration.

Our investigation showed that seminal plasma contained a fraction very active in stimulating mycelium production by Candida albicans and the presence of this fraction in the female genital tract could be a factor in determining the increased incidence of Candida vaginitis: similarly its presence under the prepuce could be a factor in balanitis.

We thank the Huddersfield Hospitals Management Committee and Leeds Regional Hospital Board for financial support for T.A. and for the purchase of equipment; Mr W. K. Hunter of the Milk Marketing Board for providing the bovine semen samples; Dr N. H. Axelsen, University of Copenhagen, for crossed immunophoretic examination of a serum fraction; Dr R. L. Noble for analyses of serum components; Mr B. J. Wormersely for assistance with gel filtration; and Dr E. J. Wood for examination of fractions in the ultracentrifuge.

\section{REFERENCES}

ANNAN, W. \& Isherwood, D. M. (1969). An automated method for the direct determination of total serum cholesterol. Journal of Medical Laboratory Technology 26, 202-21 I.

Barlow, A. J. E. \& Chattaway, F. W. (1971). Factors influencing the growth of Candida albicans in tissue fluids. In 5th International Congress of Human and Animal Mycology. Comptes rendus des Communications, pp. 49-50. Paris: Pasteur Institute.

Bernander, S. \& EDEbo, L. (1969). Growth and phase conversion of Candida albicans in Dubos medium. Sabouraudia 7, 146-155.

Caroline, L., Taschdjan, C. L., Kozinn, P. I. \& Schade, A. L. (I964). Reversal of serum fungistasis by the addition of iron. Journal of Investigative Dermatology 42, 415-419.

Chattaway, F. W., Bishop, R., Holmes, M. R., Odd, F. C. \& Barlow, A. J. E. (1973). Enzyme activities associated with carbohydrate synthesis and breakdown in the yeast and mycelial forms of Candida albicans. Journal of General Microbiology 75, 97-109.

Chattaway, F. W., Holmes, M. R. \& Barlow, A. J. E. (1968). Cell wall composition of the mycelial and blastospore forms of Candida albicans. Journal of General Microbiology 51, 367-376.

DABRoWA, N. (1971). Germination in Candida albicans. In 5 th International Conference in Human and Animal Mycology. Comptes rendus des Communications, pp. 51-52. Paris: Pasteur Institute.

De PALma, P. A. (1966). Biochemical and structural variations in the cell wall of Candida albicans under conditions of controlled morphogenesis. Thesis, Boston University Graduate School, U.S.A.

GitTleman, H. J. (1967). An improved automated procedure for the determination of calcium in biological specimens. Analytical Biochemistry 18, 52 I-531.

Gresham, C. A. \& Whittle, C. H. (1961). Studies of the invasive mycelial form of Candida albicans. Sabouraudia I, 30-33.

Lowry, O. H., Rosebrough, N. J., Farr, A. L. \& Randall, R. J. (195I). Protein measurement with the Folin phenol reagent. Journal of Biological Chemistry I93, 265-275.

Mardon, D., Balish, E. \& Philips, A. W. (1969). Control of dimorphism in a biochemical variant of Candida albicans. Journal of Bacteriology 100, 701-707.

Marsh, W. H., Fingerhut, B. \& Miller, H. (1965). Automated and manual direct methods for the determination of blood urea. Clinical Chemistry I1, 624-627.

Nickerson, W. J. \& MANKowsKi, Z. (1953). Role of nutrition in the maintenance of the yeast shape in Candida. American Journal of Botany 40, 584-592.

Nickolss, L. S. (1960). A modified Cavett method for the determination of alcohol in body fluids. Analyst $85,840-842$. 
PICKART, L. \& ThALER, M. M. (1973). Tripeptide in human serum which prolongs survival of normal liver cells and stimulates growth in neoplastic liver. Nature New Biology 243, 85-87.

Robson, J. E. \& StockLeY, H. M. (1962). Sulphydryl metabolism of fungi grown in submerged culture. Journal of General Microbiology 28, 57-68.

Spellacy, W. N. \& CARLson, K. L. (I965). Plasma insulin and blood glucose levels in patients taking oral contraceptives. American Journal of Obstetrics and Gynaecology 95, 474-478.

TASChDJiAn, C. L. \& KozinN, P. I. (1957). Laboratory and clinical studies in Candidiasis in the newborn infant. Journal of Pediatrics 50, 426-433.

TASCHDJiAn, C. L. \& KozInN, P. I. (1961). Metabolic studies of the tissue phase of Candida albicans induced in vitro. Sabouraudia $1,73-82$.

VAN UdEN, N. (1961). The occurrence of Candida and other yeasts in the intestinal tract of animals. Annals of the New York Academy of Sciences 89, 59-68.

WALSh, H., Hildebrandt, R. J. \& PrYstowsKY, H. (1968). Oral progestational agents as a cause of Candida vaginitis. American Journal of Obstetrics and Gynecology rox, $991-993$.

WIDRA, A. (1964). Phosphate directed Y-M variation in Candida albicans. Mycopathologia et mycologia applicata 23, 197-203.

YounG, D. S. (1966). Improved method for the automatic determination of serum inorganic phosphate. Journal of Clinical Pathology 19, 397-399.

Young, D. S. \& Hicks, J. M. (1965). Method for the automatic determination of serum iron. Journal of Clinical Pathology 18, 98-102. 